\title{
A CONTRIBUTION TO THE PATHOLOGY OF THE RHEUMATOID TYPE OF ARTHRITIS AND OF RHEUMATIC FEVER (ABSTRACT)*
}

\author{
By A. G. TIMBRELL FISHER
}

OUR knowledge of the pathological changes in the rheumatoid type of arthritis of so-called " unknown ætiology" (synonyms: rheumatoid, atrophic and proliferative arthritis) has been hitherto founded chiefly upon the descriptions of Nichols and Richardson (1910), Strangeways (1918), and others. It is important to realise, however, that these observations are largely based upon investigations in the later stages of the disease, or even the stage of "sequels." The rheumatoid type of arthritis is rarely fatal per se, so that opportunities for investigation of the pathological changes in the earlier or acute stages seldom occur, and many of the existing pathological descriptions are based upon post-mortem examinations of elderly sufferers who have died of some intercurrent disease and in which the essential pathological features have become obscured by secondary osteo-arthritic or other changes. The same criticism applies to material hitherto obtained at operation, since there were few indications for surgery in the active stages of rheumatoid disease. Post-mortem examinations of patients who have succumbed to rheumatic fever are, of course, frequently performed, but few would deny that the changes in the joints in such cases have not received the consideration that they deserve.

\section{Sodrce of Material}

The author has found that the operation of arthrotomy followed by lavage with an antiseptic solution is of great value in certain acute or subacute forms of arthritis of the rheumatoid type, particularly when such large and comparatively superficial joints as the knee are principally affected. In some subacute cases, partial synovectomy has been performed. The results in the

* Discussion on the Atiology of Acute Rheumatism and Rheumatoid Arthritis. B.M.A. Annual Meeting, Plymouth, Pathology Section, July 20, 1938. 
form of subsidence of acute symptoms and rapid lowering of the sedimentation rate in cases which have obstinately resisted other forms of treatment are often striking.* These operative procedures have, moreover, the great advantage of providing opportunities for the pathological and bacteriological investigation of the joint tissues and fluids from early cases, the lack of which has previously been a serious obstacle to research. A short abstract will be given of the author's investigations into the pathological histology of the synovial membrane in the earlier stages of the rheumatoid type of arthritis, and comparison made with the synovial changes in acute rheumatism, material from the latter cases being kindly provided by Professor H. M. Turnbull and Dr. W. G. Barnard, to whom the author owes a debt of gratitude for their help and criticism. The bacteriological aspect of the investigation has been undertaken by Dr. G. Hardy Eagles (q.v.).

\section{Pathological Changes}

The pathological histology of the synovial membrane in the active stages of the rheumatoid type of arthritis shows a striking similarity to the changes seen in the synovial membrane in rheumatic fever. Attention is particularly drawn to the occurrence of giant cells of the Aschoff type in the rheumatoid type of arthritis and to the presence in the same disease, as an almost constant feature, of areas of fibrinoid degeneration. This form of degeneration, together with Aschoff giant cells, are well recognised features of the lesions of rheumatic fever, but do not appear to have been previously observed in this country in the rheumatoid type of arthritis, although Klinge and Grzimek drew attention to the existence of fibrinoid degeneration in the latter disease in 1932.

\section{Illustrative Cases $\dagger$}

1. Rheumatom Type of ARthritis.-The patient was a married woman aged sixty-two. Nine months before operation painful swelling in the right ankle suddenly developed, followed two weeks later by similar

* A paper upon this aspect is in course of preparation. See also author's case, "Rheumatoid Arthritis treated by Multiple Arthrotomy and Lavage," O. A. Savage, Lancet, September 3, 1938.

† For a more detailed description see " A Contribution to the Pathology of the Rheumatoid Type of Arthritis and of Rheumatic Fever: The Rheumatic Diseases," Arnold and Co., 1938; and the Lancet, May 15, 1937, p. 1162. 
symptoms in the right knee. She received electrical treatment for several weeks and the joints improved; but soon the left knee, the right wrist, and the metacarpo-phalangeal joints of the right index and second fingers became involved. All joints, except the left knee, responded to medical and physical treatment. No toxic focus could be discovered.

Operation.-Long parapatellar incision on inner side of left knee. The synovial membrane showed hypertrophy of the synovial fringes and was œdematous in places. Much fibrinoid material was present, not only in shreds in process of exfoliation from the synovial membrane, but free in the joint. Early pannus extended for a short distance over the lateral portions of the femoral condyles, but the articular surfaces were otherwise uninvolved. Partial synovectomy was performed and the joint irrigated

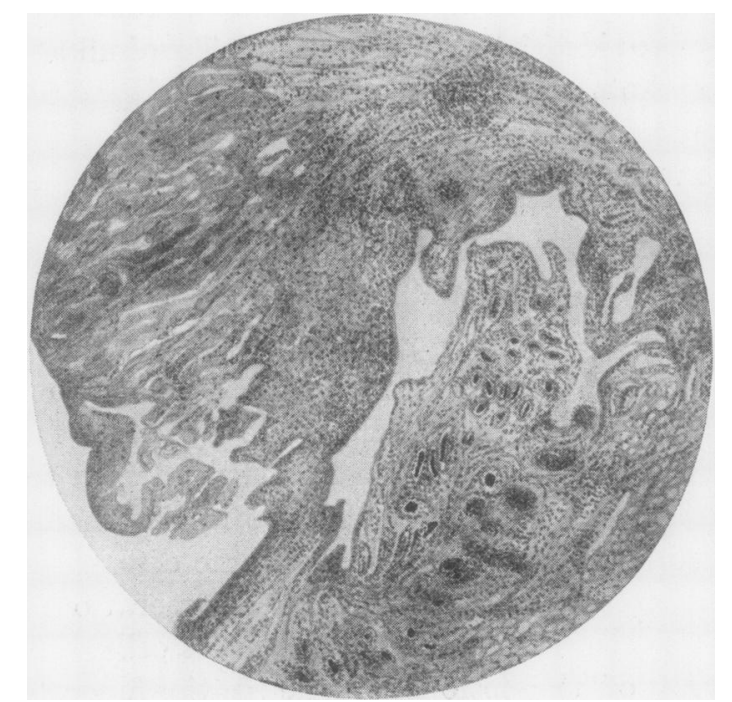

Fig. 1 (Case 1).-Rheumatom Type of Arthrits.

Section of synovial membrane $(\times 70)$. Showing large area of fibrinoid degeneration above and to the left, and several focal collections of cells in the deeper layers.

with Dakin's solution. Bacteriological investigation of synovial tissues and fluid was negative. The infrapatellar pad of fat was chosen for microscopical examination.

Several large areas of fibrinoid degeneration, not only of the superficial area, but lying more deeply, were clearly shown (Fig. 1). At this stage of the disease it is usually to be noted that the synovial membrane is diffusely infiltrated with chronic inflammatory cells, principally lymphocytes, plasma cells, and epithelioid histiocytes, in addition to the typical perivascular collections of cells previously described. In this type of case, giant cells of the Aschoff type can usually be observed (Fig. 2) if the smaller perivascular collections are examined, rather than the areas diffusely infiltrated with chronic inflammatory cells. 
A. G. TIMBRELL FISHER

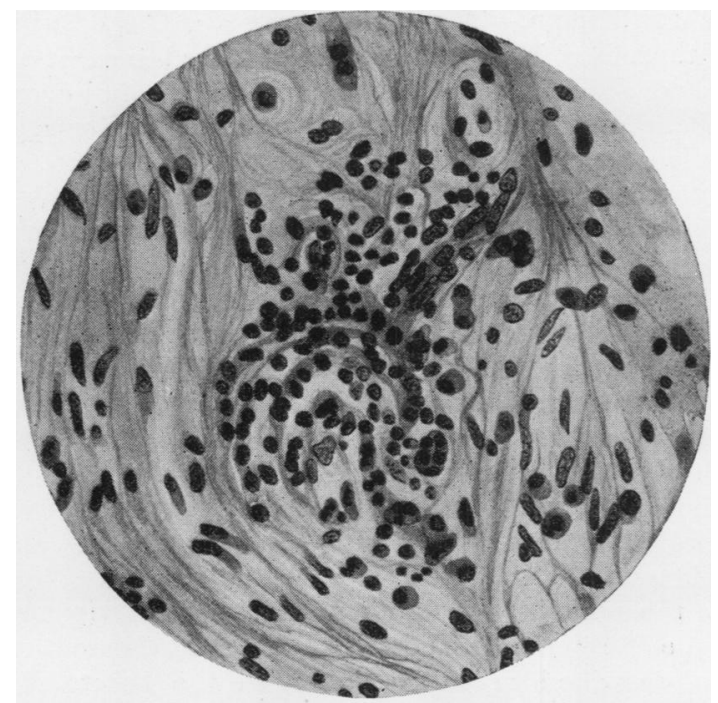

Fig. 2 (Case 1).-Rheumatoid Type of Arthritis.

Section of synovial membrane $(\times 210)$. Small focal collection of cells under higher power showing gient cells of Aschoff type.

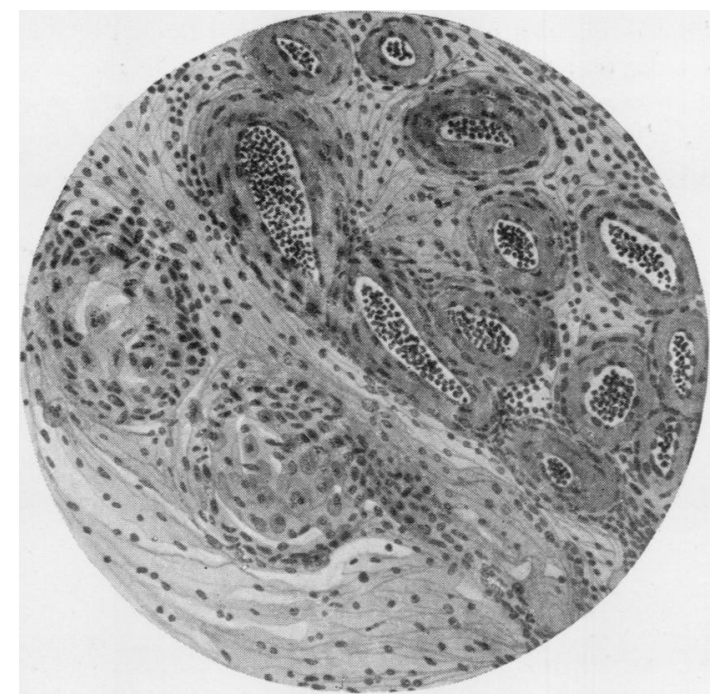

Fig. 3 (Case 2).-Rheumatic Fever.

Section of synovial membrane $(\times 120)$. Above and to the right are several bloodvessels showing fibrinoid degeneration of the subintimal layer. Below and to the left are two Aschoff bodies with typical giant cells. 
2. Rheumatic Fever.-The patient was a girl aged nine. She was admitted to St. Charles' Hospital a fortnight after the onset of illness with temperature and pain in the right elbow, which, however, ceased on admission. Pain and swelling of both ankles commenced three days before admission and the ankle-joints were hot, swollen, and painful. The temperature on admission was $99 \cdot 8^{\circ}$, the pulse-rate 144 , and respirations 26. The heart was not enlarged, but a mid-diastolic mitral murmur was present.

Two weeks later, the patient became gravely ill, with extreme restlessness and incontinence. The heart was now enlarged, with canter rhythm and loud apical systolic bruit. The patient gradually sank and died. The post-mortem examination by Dr. Barnard revealed œdema of medulla, pons, mid-brain, basal ganglia and parietal lobe of brain, rheumatic synovitis of the sterno-clavicular articulation, partially organised fibrinous pericarditis with Aschoff nodes in myocardium, rheumatic mitral endocarditis, œdema of lung with fibrinous pleurisy, and congestion of liver and kidneys.

Sections of the synovial membrane of the sterno-clavicular joint reveal many of the specific histological features of acute rheumatism that have so often been described in connection with the heart. Fibrinoid degeneration is a prominent feature $(a)$ of certain of the synovial villi and of the surface of the synovial membrane, $(b)$ scattered diffusely throughout the synovial membrane, and $(c)$ in connection with the inner coats of many of the bloodvessels so that the wall appears to be thickened. Many of the capillaries are blocked by proliferation of the endothelial layer. Around many of the bloodvessels are collections of cells in connection with the adventitia. These cells are mainly large and small lymphocytes and epithelioid histiocytes, with occasional plasma and mast cells. Among the histiocytes are some giant cells which have two, three, or even more nuclei (Fig. 3). These collections of cells resemble, therefore, the Aschoff bodies seen in the heart.

\section{COMMENTARY}

The results obtained in the course of this investigation appear to show that the pathological histology of the synovial tissues in the more acute stages of the rheumatoid type of arthritis and in acute rheumatism presents a similar and specific picture. The similarity of the pathological reactions in the synovial membrane in these clinical conditions supports the theory that they are manifestations of the same fundamental pathological process. Charcot (1881) wrote in this connection: " There are not two fundamentally distinct diseases, but only two manifestations of one and the same diathetic state "; and Hawthorne (1900) considered that the presence of similar subcutaneous nodules in the two diseases showed that they were intimately related. Of recent years, these subcutaneous nodules have been subjected to close pathological study by Coates and Coombs (1926), Freund (1928), 
Dawson (1933), Clawson and Wetherby (1932), and others, who have maintained that the pathological histology is identical in the two diseases, but Collins (1937) has more recently questioned this identity. McEwan (1933) has studied by means of supravital stains the cells of the subcutaneous nodules of both rheumatic fever and rheumatoid arthritis, and claims that the staining reactions of the cells in the two conditions are similar and differ from the cells in other granulomatous conditions, such as syphilis and tuberculosis. He has found the same specific staining reactions in the cells of the synovial membrane in rheumatoid arthritis.

It is interesting to observe that the changes that have been described in the synovial membrane, both in acute rheumatism and in the rheumatoid type of arthritis in their early stages, show a strong resemblance to the foci in the interstitial tissue of the myocardium in rheumatic fever first described by Poynton (1899), but further elaborated by Aschoff (1906), Carey Coombs (1911), and others. In this investigation, the pathological picture, the negative results of bacteriological examination of the joint tissues and fluid in uncomplicated cases, together with the absence of polymorphonuclear reaction in the synovial tissues-so characteristic of other forms of arthritis associated with the presence of pyogenic organisms-is not in agreement with the hypothesis that the rheumatoid type of unknown ætiology is due to the actual presence in the joint itself of streptococci or other pyogenic organisms. It is a significant fact also that in a few cases, in which streptococci were isolated from the synovial membrane, typical pyogenic membrane was observed, intensely infiltrated with polymorphonuclear cells, and it is important to note that definite toxic foci were present in these patients in contradistinction to the previous group. It would appear that in these cases secondary infection has been superimposed upon some other factor, the nature of which is still undecided.

The ætiological aspects of this research are discussed by Dr. G. Hardy Eagles.

\section{REFERENCES}

Allison, N., and Ghormley, R. K. (1931): "Diagnosis in Joint Disease." New York and London.

Aschoff, L., AND Tawara, S. (1906): Brit. Med. Journ., $2,1103$.

Charcot, J. M. (1881): " Clinical Lectures on Senile and Chronic Diseases." New Sydenham Society, London. 
Clawson, B. J., and Wetherby, M. (1932): Amer. Journ. Path., 8, 283. Coates, V., ANd Coombs, C. F. (1926): Arch. Dis. Child., 1, 183.

Collins, D. H. (1937): Journ. Path. Bact., 45, 97.

Coombs, C. (1910-11): Journ. Path. Bact., 15, 489.

DAwson, M. H. (1933): Journ. Exp. Med., 5\%, 845.

Fisher, A. G. T. (1922-23): Brit. Journ. Surg., 10, 52.

Fisher, A. G. T. (1923): Brit. Med. Journ., 2, 102.

Frsher, A. G. T. (1929): "Chronic (Non-Tuberculous) Arthritis." London.

Freund, E. (1928): Wien. Arch. inn. Med., 16, 73.

HAWTHORNE, C. O. (1900): "Rheumatism, Rheumatoid Arthritis and Subcutaneous Nodules." London.

Hoffa, A., and Wollenberg, G. A. (1908): "Arthritis Deformans und sogenannter chronischer Gelenkrheumatismus." Stuttgart.

Kuinge, F., AND GrzimeK, N. (1932): Virchow's Arch., 284, 646; 286, 333 and 344.

McEwen, C. (1933-34): Amer. Heart Journ., 9, 101.

NeUmann, E. (1888): Arch. mikrosk. Anat., 18, 130.

Neumane, E. (1896): Virchow's Arch., 144, 201.

Nichols, E. H. (1910): "Arthritis Deformans." Boston.

Nichols, E. H., AND RichaRdson, F. L. (1909-10): Journ. Med. Res., $21,149$.

\title{
HEBERDEN'S NODES IN A GIRL OF FIFTEEN YEARS OF AGE
}

\author{
By J. Barnes Burt, M.D.
}

K. M. S., female, age fifteen, was admitted to the Devonshire Hospital complaining of pains in the feet, hands, shoulders and spine. There was a history of pain in the hands for two years and in the elbows for some time longer. Two years previously she had been in bed for two months for some vague spinal trouble.

Previous Diseases.-Various children's ailments not specified. Tonsillectomy had been performed the previous year.

Family History.-One aunt suffered from phthisis; no history of gout or rheumatism.

Condition on Admission.-Child was fat, well nourished, and of good colour. There was some thickening of all the joints of her fingers and Heberden's nodes on all the fingers of both hands. There was some tenderness over the dorsal vertebræ, but no sign of deficiency of movement or spondylitic changes. There was definite panniculitis over the inner side of both knees, and the 